\title{
Performance of broiler chickens fed diets containing rice offal supplemented with enzyme
}

${ }^{1}$ Edache, J. A., ${ }^{2}$ Tuleun, C. D., ${ }^{1}$ Yisa, A. G., ${ }^{3}$ Muduudtai, U. R., ${ }^{2}$ Edache, D. O. and ${ }^{1}$ Mark, E. T.

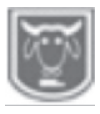

Abstract

${ }^{I}$ Federal College of Animal Health and Production Technology, Vom, ${ }^{2}$ University of Agriculture, Makurdi. ${ }^{3}$ College of Education,

A feeding trial of six weeks was conducted to determine the effect of including rice offal supplemented with natuzyme on the performance of broilers. One hundred and seventy two 2 -week old broilers of mixed sexes were randomly allocated to four diets in a completely randomized design. The broiler chicks were allocated one of four diets containing either 0 (control), 5, 10, or 15\% of rice offal. The starter diets were isonitrogenous $(25 \% \mathrm{CP})$ but decreased in energy levels from 2,779.32 (Diet A), 2,747.73 (Diet B), 2,715.54 (Diet C) to 2,683.54kcal/kg ME (Diet D). The finisher diets were also isonitrogenous at $21 \% \mathrm{CP}$ with each diet replicated three times. The energy levels of the finisher diet decreased from 2801.67 (diet A) to $2703.22 \mathrm{kcal} / \mathrm{kg} \mathrm{ME}$ (diet D). The energy levels on diets B (2768.72) and C (2736.18) were higher than on diet D. All diets containing rice offal were supplemented with natuzyme at $100 \mathrm{~g} / 100 \mathrm{~kg}$ feed. Overall result showed that feed intake was significantly lower $(p<0.05)$ on the control $(117.38 \mathrm{~g} /$ bird/day) than on diets $B$ (123.57), $C(125.24)$ and $D$ (123.97g/bird/day). Weight gain was significantly higher $(p<0.05)$ on diet $B(57.64 \mathrm{~g} / \mathrm{bird})$ than on diets $C(50.77)$ and $D(46.88 \mathrm{~g} / \mathrm{bird})$ respectively. Water intake was significantly lower $(p<0.05)$ on the control $(204.60 \mathrm{~mL} /$ bird $)$ than on diets $B(240.44), C(231.86)$ and $D$ $(225.73 \mathrm{~mL} / \mathrm{bird})$, respectively. Feed conversion ratio was significantly better $(p<0.05)$ on diets $A$ (2.36), $B$ (2.23) and $C$ (2.68) than on diet $D$ (3.06) only. Feed cost/kg gain was significantly $(p<0.05)$ better on diet $A(N 532.65)$ than on diets $B(N 666.75)$ and $C$ (N688.92) only. Initial weight did not differ significantly across the diets but final weight was better $(p<0.05)$ on diet B $(2644.40 \mathrm{~g} / \mathrm{bird})$ than on the control and other rice offal diets. Even though the control diet had lower feed intake, birds on diet B had better weight gain, feed conversion ratio, feed cost/gain and final body weight than the control and other rice offal diets and is therefore, recommended. This is because rice offal based diet on diet $B$ has a cost saving of $8.33 \%$ over the control diet.

Keywords: Rice offal, natuzyme, water intake, Japanese quails.

\section{Introduction}

Concerted efforts being made to explore cheap feed resources for animal production have the capacity to lower the market price of poultry products and therefore make more animal protein available for the growing human population. Erratic changes in price of feed materials constantly force feed manufacturers to change formula used to produce feed in order to maintain reasonable gross margin. Rice is a major staple food in most developing nations. FAO (2017) reported that preliminary forecast of global paddy production in 2017 is set at 758.9 million tonnes. The husk (the outer rough covering) produced from this rice is either burnt off or heaped as wastes but more recently is being used sparingly in poultry diets due to the high fibre content. Carew et al. (2005) and Makinde et al. (2014) have studied the use of agro-industrial by products (rice offal, maize offal, wheat offal, brewer's dried grain and palm kernel meal) to replace cereal grains in poultry diets. These agro industrial by products have elicited some levels of improvement when fed to broiler chickens at lower levels (Yakubu et al., 


\section{Performance of broiler chichens fed diets containing rice offal}

2007; Makinde et al., 2014). Rice milling waste has been reported to reduce production cost, produce lean meat and supply nutrients like vitamins and minerals and other unidentified factors which improve growth (Ojewola and Ewa, 2005). However, as high as $80 \%$ inclusion of these by products may result in low calcification, decreased feed intake, poor digestibility and even mortality (Bae et al., 1997; Aruna and Singh, 1999). Agbede et al. (2002) had shown that high fibre and lignin content of rice husks are capable of reducing nutrient utilization and also precipitate metabolic dysfunction when digested by nonruminants. Therefore, it becomes necessary to incorporate exogenous enzymes in monogastric animal diets to enhance the breakdown of non-starch polysaccharides (NSP) in rice offal. According to Allen et al. (1997), inclusion of enzyme in monogastric animal diets reduces viscosity of the intestinal ingesta and shows a marked improvement on the various morphological effects of feeding fibrous materials. The action of exogenous enzymes such as maxigrain or natuzyme is the solubilizing of cell wall of high fibre feedstuff such as rice offal.

The objective of this study is to determine the effect of dietary inclusion of rice offal supplemented with natuzymeon the performance of broilers.

\section{Materials and methods}

\section{Birds, housing and management}

Seventy-two, 2-week old broilers of mixed sexes (of the breed arbor arcre) having a trade name 'agrited' obtained from an agent in Jos, Plateau State but linked to a hatchery based in Yola, Adamawa State, Nigeria were used in this study. They were uniform in size and housed in deep litter house partitioned into several pens with wire mesh to allow for adequate ventilation. The birds occupied 12 pens with 6 birds per pen. The birds were offered one of four diets containing either 0 (control), 5, 10 or $15 \%$ of rice offal at eighteen birds per diet. The birds were randomly allocated to the diets in a completely randomized design. The experimental diets were designated A, B, C and $D$ respectively. All birds from each unit were weighed at the beginning and weighed weekly. All vaccination schedules and management procedures were strictly adhered to. Feed and water were given ad libitum for six weeks.

\section{Rice offal}

Rice offal was purchased from feed material shops or sales points in Bukuru, Jos South LGA of Plateau State. They were obtained dry and incorporated into the diets free from mould and weevils.

\section{Experimental diets}

Four isonitrogenous $(25 \% \mathrm{CP})$ diets containing graded levels $(0$, (control) $, 5,10$, and $15 \%$ ) of rice offal were used in this study. The diets containing rice offal were treated with Natuzyme ${ }^{\mathrm{TM}}$ at the rate of 100 grams per 100 kilogram of the diet and were mixed homogenously to achieve a complete blend. Natuzyme contains phytase, $\beta$-glucanase, $\alpha$-amylase, cellulase, pectinase, amyloglycosidase, xylanase and protease. The diets were designated A, B, C and $\mathrm{D}$ respectively in the starter phase (Table 2) and contained metabolizable energy (ME) levels; 2,779.32, 2,747.73, $2,715.54$ and $2,683.54 \mathrm{kcal} / \mathrm{kg} \mathrm{ME}$ respectively while in the finisher phase (Table 3), the crude protein level was held at $21 \%$ but the energy levels decreased from 2801.67 (diet A) to $2703.22 \mathrm{kcal} / \mathrm{kg} \mathrm{ME}$ (diet D). The ME levels on diets B (2768.72) and C (2736.18) were higher than on $\operatorname{diet} \mathrm{D}$.

\section{Data collection and analysis}

The mean weekly body weights, water intake and feed intake were recorded throughout the experimental period. From the mean body weight and feed intake, feed conversion ratio was calculated. Feed $\operatorname{cost} / \mathrm{kg}$ gain and feed cost $/ \mathrm{kg}$ diet was 


\section{Edache, Tuleun, Yisa, Muduudtai, Edache and Mark}

calculated from prevailing local market price of feed materials. Data collection was subjected to analysis of variance; ANOVA (Steel and Torrie, 1980) and where significant differences occurred, means were separated by Duncan's new multiple range test (Obi, 1990). The analysis was carried out using Minitab version 14 (Minitab, 1991).

\section{Results and discussion}

Feed intake, water intake, weight gain and feed conversion ratio are presented in Table 1. Feed intake increased significantly as the level of rice offal increased in the diet. It was higher on diets $\mathrm{C}$ and $\mathrm{D}$ than on $\operatorname{diet} \mathrm{A}$. This is contrary to the similarity in feed intake reported by Fafiolu et al. (2010) for meat-type chicken fed rice offal based diets. However, significant effect of rice offal diet on feed intake of grower turkeys has been reported by Makinde et al. (2015).
They reported significantly lower feed intake onthe diet containing rice offal compared to intake by birds on diets containing maize offal or wheat offal. This has been attested to by Ajala et al. (2003) who reported decreased nutrient utilization of birds fed high fibre diets. The significant increase in feed intake noted in this study may be as a result of solubilizing of cell wall by exogenous enzyme of high fibre rice offal (IFRU, 2003) and also because birds eat to satisfy energy requirement more so the energy level of the diets was decreasing. Water intake followed similar trend. Abeke et al. (2011) has reported similar result. Values for water intake reported in this study are close to those $(107-232 \mathrm{~mL} / \mathrm{b} / \mathrm{d})$ reported by Abeke et al. (2011). Laxative effect of dietary fibre on the gut of chicken has been reported by Ani et al. (2010) which might lead to increased gastric evacuation. This may in turn cause thirst leading to increased water intake.

Table 1: Effects of various rice offal levels on parameters measured

\begin{tabular}{llllll}
\hline Parameters & A & B & C & D & SEM \\
\hline Feed intake $(\mathrm{g} / \mathrm{b} / \mathrm{d})$ & $117.38^{\mathrm{a}}$ & $123.57^{\mathrm{b}}$ & $125.24^{\mathrm{b}}$ & $123.97^{\mathrm{b}}$ & $2.08^{*}$ \\
Water intake $(\mathrm{ml} / \mathrm{b} / \mathrm{d})$ & $204.60^{\mathrm{a}}$ & $240.44^{\mathrm{b}}$ & $231.86^{\mathrm{b}}$ & $225.73^{\mathrm{b}}$ & $7.21^{*}$ \\
Weight gain $(\mathrm{g} / \mathrm{b} / \mathrm{d})$ & $52.79^{\mathrm{ab}}$ & $57.64^{\mathrm{b}}$ & $50.77^{\mathrm{a}}$ & $46.88^{\mathrm{a}}$ & $2.29^{*}$ \\
Feed/gain ratio & $2.36^{\mathrm{a}}$ & $2.23 \mathrm{a}$ & $2.68 \mathrm{a}$ & $3.06^{\mathrm{b}}$ & $0.21^{*}$ \\
Feed cost/kg gain & $275.22^{\mathrm{a}}$ & $251.57^{\mathrm{a}}$ & $294.18^{\mathrm{a}}$ & $327.12^{\mathrm{b}}$ & $22.26^{*}$ \\
Initial weight $(\mathrm{g} / \mathrm{b}$ ird $)$ & 227.22 & 223.89 & 217.78 & 231.11 & $10.58 \mathrm{NS}$ \\
Final weight $(\mathrm{g} / \mathrm{bird})$ & $2444.40^{\mathrm{a}}$ & $2644.40^{\mathrm{b}}$ & $2350.00^{\mathrm{a}}$ & $2200.00^{\mathrm{a}}$ & $98.80^{*}$ \\
\hline a,b. Means with different superscripts within a row differ significantly $(\mathrm{P}<0.05)$ SEM $=$ standard error of mean, N.S $=$ not significant
\end{tabular}

Weight gain on the other hand was higher on the diet containing $5 \%$ rice offal than on those containing 10 and $15 \%$. There are some similarities between the results of this study and that of Ani et al. (2010). Whereas in their study weight gain decreased in nonenzyme supplemented high fibre diets, in this study the decrease was observed after the $5 \%$ level of inclusion of rice offal suggesting that to a point, the exogenous enzyme helped the birds to utilize the nutrients in the feed.Feed conversion ratio and feed cost $/ \mathrm{kg}$ gain were significantly better for birds on the control, on 5 and on $10 \%$ level of inclusion than on the $15 \%$ level of inclusion suggesting some improvement in the utilization of nutrients by the broilers. Similar result has been published by Abeke et al. (2011). The poorer ability of birds on the $15 \%$ level of inclusion of rice offal to convert the diets to flesh compared to the control and the other diets maybe due to incomplete break down of non-starch polysaccharides (NSP) in the fibre contained in rice offal.by exogenous enzymes. Timbrell (1992) had observed that there could be instances where enzyme additions or supplementation add little value to particular ingredients or fail to result in improved performance. The 


\section{Performance of broiler chickens fed diets containing rice offal}

exogenous enzyme might have enhanced a less viscous digesta leading to improved digestion resulting in the similarity in improvement in feed conversion ratio and feed cost/gain. Therefore, the 5\% level of inclusion of rice offal is recommended.

Table 2. Composition of experimental diets (Starter phase; \%)

\begin{tabular}{|c|c|c|c|c|}
\hline \multirow{2}{*}{ Ingredients } & \multicolumn{3}{|c|}{ Diets } & \multirow[b]{2}{*}{$\mathrm{D}$} \\
\hline & $\mathrm{A}$ & $\mathrm{B}$ & $\mathrm{C}$ & \\
\hline Maize & 39.81 & 34.40 & 28.98 & 23.55 \\
\hline Rice offal & 0.00 & 5.00 & 10.00 & 15.00 \\
\hline Ground nut cake & 41.99 & 42.40 & 42.82 & 43.25 \\
\hline Palm kernel cake & 13.50 & 13.50 & 13.50 & 13.50 \\
\hline Fish meal & 0.50 & 0.50 & 0.50 & 0.50 \\
\hline Bone meal & 2.00 & 2.00 & 2.00 & 2.00 \\
\hline Lime stone & 1.50 & 1.50 & 1.50 & 1.50 \\
\hline Premix & 0.25 & 0.25 & 0.25 & 0.25 \\
\hline Common salt & 0.25 & 0.25 & 0.25 & 0.25 \\
\hline Methionine & 0.10 & 0.10 & 0.10 & 0.10 \\
\hline Lysine & 0.10 & 0.10 & 0.10 & 0.10 \\
\hline \multirow[t]{2}{*}{ Natuzyme } & - & $*$ & $*$ & $*$ \\
\hline & 100 & 100 & 100 & 100 \\
\hline \multicolumn{5}{|c|}{ Calculated composition $\%$} \\
\hline $\mathrm{CP}$ & 24.99 & 25.00 & 25.00 & 25.00 \\
\hline $\operatorname{ME}(\mathrm{Kcal} / \mathrm{kg})$ & 2779.32 & 2747.73 & 2715.54 & 2683.50 \\
\hline $\mathrm{Ca}$ & 1.38 & 1.38 & 1.39 & 1.40 \\
\hline $\mathrm{P}$ & 0.44 & 0.45 & 0.49 & 0.50 \\
\hline $\mathrm{CF}$ & 4.58 & 5.12 & 5.65 & 6.19 \\
\hline Feedcost $/ \mathrm{kg}(\AA)$ & 90.74 & 86.60 & 82.44 & 78.29 \\
\hline \multicolumn{5}{|c|}{$\begin{array}{l}\text { * Bio Mix Layer premix supplied the following per 100kg of diet: Vitamin A, } 850,000 \text { I.U; Vitamin D3,150,000 I.U; Vitamin E, 1,000 I.U; Vitamin K, } \\
1000 \mathrm{mg} \text {; Thiamin (B1), } 150 \mathrm{mg} \text {; Riboflavin (B2), 450mg; Pyridoxine (B6), 300mg; Niacin, 1500mg; Vitamin B12, 1.5mg;Pantothenicacid, } 450 \mathrm{mg} \text {; } \\
\text { Folic acid, 60mg; Biotin, } 50 \mathrm{mg} \text {; Choline chloride, 17,500mg; Anti-oxidant, 125mg; Manganese, 4000m;; Zinc, 3000mg; Iron, 2000mg; Copper, } \\
\text { 300mg; Iodine, 100mg; Selenium, 20mg; Cobalt, 20mg. Key: C.P, crude protein; M.E, metabolizable energy; Ca, calcium; P, phosphorus; C.F, crude } \\
\text { fibre }\end{array}$} \\
\hline
\end{tabular}

Table 3: Composition of experimental diets (Finisher phase; \%)

\begin{tabular}{|c|c|c|c|c|}
\hline \multirow[b]{2}{*}{ Ingredients } & \multicolumn{3}{|c|}{ Diets } & \multirow[b]{2}{*}{$\mathrm{D}$} \\
\hline & $\mathrm{A}$ & B & $\mathrm{C}$ & \\
\hline Maize & 50.93 & 45.50 & 40.11 & 34.68 \\
\hline Rice offal & 0.00 & 5.00 & 10.00 & 15.00 \\
\hline Soyabean cake & 30.37 & 30.80 & 31.19 & 31.70 \\
\hline Palm kernel cake & 13.50 & 13.50 & 13.50 & 13.50 \\
\hline Fish meal & 0.50 & 0.50 & 0.50 & 0.50 \\
\hline Bone meal & 2.00 & 2.00 & 2.00 & 2.00 \\
\hline Lime stone & 1.50 & 1.50 & 1.50 & 1.50 \\
\hline Premix & 0.25 & 0.25 & 0.25 & 0.25 \\
\hline Common salt & 0.25 & 0.25 & 0.25 & 0.25 \\
\hline Methionine & 0.10 & 0.10 & 0.10 & 0.10 \\
\hline Lysine & 0.10 & 0.10 & 0.10 & 0.10 \\
\hline \multirow[t]{2}{*}{ Natuzyme } & - & $*$ & $*$ & $*$ \\
\hline & 100 & 100 & 100 & 100 \\
\hline \multicolumn{5}{|c|}{ Calculated composition $\%$} \\
\hline $\mathrm{CP}$ & 24.99 & 25.00 & 25.00 & 25.00 \\
\hline $\mathrm{ME}(\mathrm{Kcal} / \mathrm{kg})$ & 2779.32 & 2747.73 & 2715.54 & 2683.50 \\
\hline $\mathrm{Ca}$ & 1.38 & 1.38 & 1.39 & 1.40 \\
\hline $\mathrm{P}$ & 0.44 & 0.45 & 0.49 & 0.50 \\
\hline $\mathrm{CF}$ & 4.58 & 5.12 & 5.65 & 6.19 \\
\hline Feedcost/kg( $\mathbb{N})$ & 90.74 & 86.60 & 82.44 & 78.29 \\
\hline \multicolumn{5}{|c|}{$\begin{array}{l}\text { * Bio Mix Layer premix supplied the following per 100kg of diet: Vitamin A, 850,000 I.U; Vitamin D3,150,000 I.U; Vitamin E, 1,000 I.U; } \\
\text { Vitamin K, } 1000 \mathrm{mg} \text {; Thiamin (B1), } 150 \mathrm{mg} \text {; Riboflavin (B2), 450mg; Pyridoxine (B6),300mg; Niacin, 1500mg; Vitamin B12, } \\
\text { 1.5mg;Pantothenic acid, 450mg; Folic acid, 60mg; Biotin, 50mg; Choline chloride, 17,500mg; Anti-oxidant, 125mg; Manganese, 4000mg;, } \\
\text { Zinc, 3000mg; Iron, 2000mg; Copper, 300mg; Iodine, 100mg; Selenium, 20mg; Cobalt, 20mg. Key: C.P, crude protein; M.E, metabolizable } \\
\text { energy; Ca, calcium; P, phosphorus; C.F, crude fibre }\end{array}$} \\
\hline
\end{tabular}




\section{Edache, Tuleun, Yisa, Muduudtai, Edache and Mark}

\section{Conclusion}

Rice offal, a byproduct of rice processing mills is obtainable from several rice mills in several locations especially in rice producing communities and at times constitutes a waste disposal burden. The escalating cost of poultry feed could effectively be alleviated by use of cheaper feed resources like this. Comparison of the mean values of feed intake, feed/gain ratio and feed cost per gain showed significant differences across the diets. Even though the control diet had lower feed intake, birds on diet B had better weight gain, better feed conversion ratio, least feed cost/gain and higher final body weight than the control and other diets containing rice offal and is therefore, recommended. Furthermore, rice offal based diet on diet B has a cost saving of $8.33 \%$ over the control diet.

\section{Acknowledgement}

The authors are grateful to the Provost, Federal College of Animal Health and Production Technology, Vom for the support.

\section{References}

Abeke, F. O., Wayebo, H. K., Sekoni, A. A., Out, M. and Ubani, E. O. 2011. Effect of graded levels of rice offal on the performance of broiler starter. Proc. $36^{\text {th }}$ Ann. Conf. Nig. Soc. Anim. Prod.(NSAP). University of Abuja, Abuja, Nigeria, 13-16 March, pp355-358

Agbede, J. O., Ajaja, K. and Aletor, V. A. 2002. Influence of Roxazyme $G$ supplementation on the utilization of sorghum-dust based diets for broiler chicks. Proc. $25^{\text {th }}$ Ann. Conf. Nig. Soc. Anim. Prod.(NSAP). Federal University of Technology, Akure, Nigeria, 17-21 March, pp105-108

Allen, V. M., Fernandez, F. and Hinton,
M. H. 1997. Evaluation of the influence of supplementing diet with mannose or palm kernel meal on salmonella colonization in poultry. British Poultry Science 38: 485-488.

Ajala, K., Agbede, J. O. and Aletor, V. A. 2003. Influence of roxazyme $\mathrm{G}$. supplementation on the utilization of wheat offal or rice bran by broilers. Proc. $8^{\text {th }}$ Ann. Conf. Anim. Sc. Assoc. of Nigeria (ASAN). Sept. $16^{\text {th }}-18^{\text {th }}$ University of Tech. Minna, Nigeria.pp 32-34

Ani, A. O., Alutu, O. N. and Osita, C. O. 2010. Effect of enzyme supplementation on performance of pullet chicks fed different levels of dietary fibre. Proc. $35^{\text {th }}$ Ann. Conf. Nig. Soc. Anim. Prod.(NSAP). University of Ibadan, Nigeria, 14-17 March, pp453-456

Aruna, T. S. and Singh, K. S. 1999.Femur bone mineralization of chicken fed rice offal based diets. Indian $J$. Poult. Sci., 34 (3): 332-336

Bae, J. D., McAllister, T. A., Kotto, E. G., Leggett, F. L., Yanke, L. J., Jacober, K. D., Ha, J. K., Shin, H. T., Cheng, K. J. 1997. Effect of silica and the colonization of rice straw by ruminal bacteria. Anim. Feed Sci. Technol. 65: 161-181.

Carew, S. N., Tuleun, C.D. and Yaakugh, I.D.I. 2005. The feed value of rice milling by products in broiler finisher dioets. Sustainable Trop. Agric. Res. 13: 69-73

Fafiolu, A. O., Jegede, A. V., Oso, A. O., Sobayo, R. A. and Idowu, O. M. O. 2010. Utilization of enzyme supplemented wheat offal-rice bran based diets on performance characteristics and serum biochemistry by meat-type 


\section{Performance of broiler chickens fed diets containing rice offal}

chicken. Nig. J. Anim. Prod. 37 (2): 199-206

FAO, 2017. Food and Agriculture Organization, Rice Market Monitor, vol. xx No. 1 April 2017

International Feed Resources Unit IFRU. 2003. Evaluation of the nutritive value of roughages: feed upgrading by use of enzymes. The Macaulay Land Use Research Institute Aberdeen, VK pp 1-3

Makinde, O. J., Enyigere, P. C., Babajide, S. E., Atsumbe, J. A., Ibe, E. A. and Samuel, I. 2014. Growth performance and carcass characteristics of finisher broilers fed rice offal based diets supplemented with exogenous enzyme. Greener Journal of Agricultural Sciences 4(4): 144149

Makinde, O. J., Inuwa, M., Babajide, S. E., Omotugba, S. K., Ibe, E. A., Ajibade, A. J., Mohammed, H. I., Bakare, K., Chukwudebe, E. P., Zaccheous, O.S. and Awofolajin, A. O. 2015. Response of grower turkeys to different fibre sources supplemented with exogenous enzyme. Proceedings of the $20^{\text {th }}$ Annual Conference of Animal Science Association of Nigeria; 2015, University of Ibadan, Ibadan, Nigeria, 2015.Pp 10-14

Minitab Statistical Software 1991. Minitab statistical software, Rehearse 15.0. Minitab Inc., State College, P.A. USA.
Obi, U. I. 1990. Statistical methods of detecting differences between treatment means. Snnap press $2^{\text {nd }}$ Edition, Enugu, Nigeria, pp24-35

Ojewola, G. S. and Ewa, U. E. 2005. Response of growing broilers to varying dietary plant protein.International J. Poult. Sci. 4 (10): 706-771, 2005. Asian Network for Scientific information. 2005. P.769

Steel, R. G. D and J. A. Torrie 1980.Principle and procedure of Statistics.A biometrical approach. $2^{\text {nd }}$ ed. McGraw Hill Book Co. New York, USA.

Timbrell, J. A. 1992. Principles of Biochemical Toxicology. Taylor Francis Ltd, London.

Yakubu, B., Adegbola, T. A., Bogoro, S. and Yusuf, H. B. 2007. Effect of urea treated and untreated rice offal on the performance of broilers: 1. Growth performance and economy of production. J.Sustainable Dev. Agric. Envt. (3): 7-13

Received: $14^{\text {th }}$ September, 2018

Accepted: $19^{\text {th }}$ December, 2018 